\title{
PIDANA PENGGANTI DENDA SEBAGAI BENTUK SUBSTITUSI PIDANA DALAM PERTANGGUNGJAWABAN PIDANA KORPORASI
}

\section{Adriano}

Dosen FH Universitas Hang Tuah Surabaya

\begin{abstract}
There are differences of characteristics between natuurlijke person (man) with rechtspersoon (legal entity or corporation) even though they both constitute legal subjects, these differences result on assembling of the criminal. Criminal fines become a major staple for corporate criminal in its application can not stand alone but must be accompanied by a fine substitute criminal law enforcement in order to run run well. Jika denda tidak dibayar oleh natuurlijke person, then the person liable to imprisonment for a fine substitute. So what if it happened to the corporation, the rechtspersoon certainly can not be imposed imprisonment in substitute of fine. This article will answer in detail the intricacies associated with it and how criminal that should be applied to the corporation.
\end{abstract}

Key words: Corporations, criminal and criminal substitute

\section{A. Pendahuluan}

Arah perkembangan hukum pidana terutama di Indonesia dewasa ini lebih banyak membicarakan mengenai masalahmasalah yang bersifat dogmatik, sebaliknya mengenai sistem pemidanaan atau bahkan sanksi pidananya itu sendiri tidak banyak dilakukan pengkajian mendalam, sehingga secara keseluruhan pembahasan mengenai materi ilmu hukum pidana menjadi kurang beragam dan disana-sini tampak banyak ketimpangan normative berkaitan dengan sistem pemidanaan dan sanksi pidananya itu sendiri.

Setidaknya terhitung semenjak awal reformasi hingga detik saat ini setiap produk legislasi berupa Undang-Undang selalu dicantumkan sanksi pidana, namun sayangnya ini tidak diikuti dengan kajian yang mendalam mengenai sanksi pidananya itu sendiri.

Topik tersebut menjadi suatu hal yang penting karena sebenarnya sebagai ultimum remedium pencantuman sanksi pidana dalam suatu ketentuan undangundang bukan saja ingin dicobakesankan agar menimbulkan efek jera pada calon pelaku kejahatan dan masyarakat pada umumnya, namun juga harus dipikirkan dan dikaji mengenai ketepatan maupun efektivitasnya manakala suatu sanksi pidana itu benar-benar diterapkan terhadap para pelaku kejahatan, terutama dalam kejahatan-kejahatan yang melibatkan atau pelakunya adalah suatu Korporasi (lazim 
disebut dengan kejahatan korporasi), sehingga dalam konteks yang lebih luas pencantuman ancaman sanksi pidana itu tidak justru akan menimbulkan kesan latah, bahwa setiap undang-undang jika ingin efektif dalam penerapannya maka harus disertai pencantuman sanksi pidana, melainkan semestinyalah sanksi pidana itu benar-benar dapat diterapkan dan efektif.

Dalam kejahatan-kejahatan yang dianggap dimungkinkan dapat dilakukan oleh suatu Korporasi, maka jika dilihat mengenai pengaturan sanksi pidananya dalam ketentuan beberapa undang-undang, sanksi pidana itu tidak mungkin diterapkan terhadap Korporasi. Sebagai contoh ketentuan dalam Pasal 103 UndangUndang Nomor 32 Tahun 2009 tentang Perlindungan Dan Pengelolaan Lingkungan Hidup, yang berbunyi : "Setiap orang yang menghasilkan limbah B3 dan tidak melakukan pengelolaan sebagaimana dimaksud dalam Pasal 59, dipidana dengan pidana penjara paling singkat 1 (satu) tahun dan paling lama 3 (tiga) tahun dan denda paling sedikit Rp1.000.000.000,00 (satu miliar rupiah) dan paling banyak Rp3.000.000.000,00 (tiga miliar rupiah)".

Ketentuan dalam Pasal 103 tersebut jika dikaji lebih lanjut menurut jenis tindak pidananya, maka sesuai dengan isi ketentuan Pasal 97 dari Undang-Undang tentang Perlindungan Dan Pengelolaan Lingkungan Hidup adalah tindak pidana kejahatan (misdrijven), dan tindak pidana kejahatan tersebut amat dimungkinkan dapat dilakukan oleh suatu Korporasi, sedangkan sanksi pidana yang diancamkan dalam Pasal 103 Undang-Undang tentang Perlindungan Dan Pengelolaan Lingkungan Hidup itu adalah berupa pidana penjara dan denda yang diterapkan secara kumulatif.

Masalah timbul ketika suatu Korporasi dinyatakan bersalah telah melakukan tindak pidana kejahatan, yakni "menghasilkan limbah B3 dan tidak melakukan pengelolaan sebagaimana dimaksud dalam Pasal 59”, dan dijatuhi pidana sesuai yang diancamkan dalam pasal tersebut yaitu pidana penjara dan denda yang diterapkan secara kumulatif. Apabila hal itu terjadi maka bukan saja bertentangan dengan penerapan sanksi pidana yang diatur secara kumulatif dalam pasal tersebut, akan tetapi juga merupakan suatu kekeliruan yang fatal, karena bagaimana mungkin suatu korporasi dapat menjalani eksekusi pidana penjara? Demikian juga mengenai pidana denda yang dijatuhkan, akan ada banyak dijumpai kendala-kendala yang harus diselesaikan dan semestinya juga harus 
diselesaikan oleh undang-undang itu sendiri sebagai suatu bagian dari system dalam penegakan hukum (law enforcement) khususnya hukum lingkungan.

Sebagai ilustrasinya adalah seorang individu manusia (natuurlijke person) yang dijatuhi pidana denda, maka apabila ia tidak membayar denda tersebut pidananya diganti dengan pidana kurungan (namanya pidana kurungan pengganti denda), namun tidaklah demikian dengan Korporasi yang tidak mungkin menjalani pidana kurungan (sebagai substitusi atau pengganti denda yang tidak dibayar) sekalipun hanya sehari.

Uraian tersebut di atas hanyalah suatu gambaran tentang bagaimana pentingnya kajian mengenai sanksi pidana yang normative akan diterapkan kepada pelaku kejahatan korporasi, agar sanksi tersebut bukan sekedar untuk menakutnakuti pelaku maupun menimbulkan efek jera pada masyarakat, melainkan merupakan sanksi yang tepat dan efektif yang apabila Korporasi terbukti bersalah melakukan suatu kejahatan, maka penjatuhan sanksi pidana tersebut terhadap Korporasi dimungkinkan untuk dijalani dan merupakan bagian terencana dari suatu sistem pemidanaan. Dengan demikian kemandirian suatu sanksi pidana menjadi penting artinya dalam suatu penegakan hukum, apakah pidana itu dapat berdiri sendiri atau pidana itu baru akan optimal jika ditopang oleh pidana pengganti (substitusi).

\section{B. Rumusan Masalah}

Berdasarkan uraian latar belakang masalah tersebut di atas, maka masalahmasalah yang akan dikaji dan sekaligus menjadi legal issue adalah sebagai berikut

1. Kemandirian pidana denda sebagai suatu sanksi dalam pertanggungjawaban pidana korporasi.

2. Bentuk pidana pengganti denda sebagai pidana substitusi yang sesuai dengan karakteristik Korporasi.

Tujuan Penelitian

Penelitian ini secara keseluruhan mempunyai tujuan sebagai berikut :

1) Mencari pembenaran secara rasional dan normative tentang pentingnya pidana denda yang diterapkan secara substitutif dengan pidana pengganti berkaitan dengan pertanggungjawaban pidana korporasi.

2) Mengembangkan kerangka konseptual tentang sanksi pidana tertentu yang tepat dan efektif bagi korporasi yang terbukti bersalah melakukan kejahatan sebagai pengganti pidana denda jika pidana itu tidak dibayar. 
Manfaat Penelitian

Selanjutnya hasil dari penelitian ini diharapkan dapat memberikan manfaat berupa sumbangan pemikiran mengenai sanksi pidana pengganti denda yang bentuknya apa dan bagaimana seharusnya sanksi itu diterapkan terhadap Korporasi yang melakukan kejahatan, sehingga penjatuhan sanksi pidana pengganti tersebut dirasakan tepat dan efektif sesuai dengan karakteristik Korporasi.

Manfaat tersebut merupakan ujud pengabdian kepada masyarakat, karena sumbangan pemikiran yang demikian ini dapat dipergunakan dan bermanfaat baik bagi pembentuk undang-undang, para penegak hukum terutama Hakim yang menjatuhkan pidana terhadap Korporasi yang dinyatakan terbukti bersalah melakukan kejahatan, juga diharapkan bermanfaat bagi pengembangan teoritik ilmu pengetahuan khususnya ilmu hukum pidana dan pemidanaan.

\section{Metode Penelitian}

Ilmu hukum sebagai ilmu sui generis, memiliki ciri khas yakni bersifat normative. Dalam kajian yang bersifat normative haruslah berpegang pada tradisi keilmuan hukum itu sendiri yang sesuai dengan karakter dan tradisi ilmu hukum. Oleh karena penelitian ini adalah penelitian hukum, maka pendekatan yang dipandang pas adalah pendekatan perundang-undangan (statute approach) dan pendekatan konseptual (conceptual approach).

Penggunaan pendekatan ini dimaksudkan untuk memperoleh kajian yang menyeluruh mengenai hal-hal yang berkaitan dengan pertanggungjawaban pidana Korporasi berikut dengan pidana dan system pemidanaannya.

Pendekatan perundang-undangan (statute approach) dilakukan dengan menelaah dari sudut filosofis undangundang yang mengatur mengenai Korporasi dapat dipertanggungjawabkan secara pidana dan dapat dipidana. Sedangkan pendekatan konseptual dilakukan dengan beranjak dari pandangan-pandangan dan konsep-konsep yang berkembang mengenai hal itu.

Selanjutnya untuk dapat menjawab permasalahan dalam penelitian ini, diperlukan sumber-sumber penelitian yang dapat dipergunakan sebagai bahan hukum primer dan bahan hukum sekunder. Bahanbahan hukum primer merupakan bahan hukum yang mempunyai autoritatif, yang terdiri dari perundang-undangan dan putusan-putusan hakim. Bahan-bahan hukum sekunder berupa semua tulisan ilmiah tentang hukum terutama yang telah dipublikasikan yang meliputi buku-buku 
teks, kamus-kamus hukum, jurnal-jurnal hukum dan lain-lain. Untuk memperoleh bahan-bahan hukum tersebut studi kepustakaan merupakan jalan terbaik untuk itu.

\section{B. Pembahasan}

Kemandirian pidana denda sebagai suatu sanksi dalam pertanggungjawaban pidana korporasi

Dalam teori ilmu hukum hingga saat ini memang tidak bisa dipungkiri masih terdapat pro-kontra mengenai apakah Korporasi dapat dipertanggungjawabkan secara pidana atau tidak, dan kalau dapat dipertanggungjawabkan maka pertanyaan berikutnya adalah apakah Korporasi juga dapat dipidana sebagaimana layaknya individu manusia. Sebelum melangkah lebih jauh mengenai pemidanaan terhadap Korporasi yang terbukti telah melakukan kejahatan, kiranya terlebih dahulu perlu dibahas satu persatu mengenai persoalan yang lebih mendetail yang terdapat dalam kejahatan korporasi (corporate crime) ini dengan dimulai dari apa yang dimaksud dengan korporasi.

\section{Korporasi.}

Menurut Soetan K. Malikoe Adil : Secara
etimologis tentang kata korporasi
(corporatie, Belanda), corporation
(Inggris), corporation (Jerman) berasal dari kata corporation dalam bahasa Latin "tio", maka corporation sebagai kata benda (subtantivum) berasal dari kata kerja corporare yang banyak dipakai orang pada abad pertengan atau sesudah itu. Corporare sendiri berasal dari kata “corpus" (Indonesia, badan) yang berarti memberikan badan atau membadankan. Dengan demikian maka akhirnya Corporatio itu hasil dari pekerjaan membadankan, dengan lain perkataan badan yang dijadikan orang, badan yang diperoleh dengan perbuatan manusia sebagai lawan terhadap badan manusia yang terjadi menurut alam. ${ }^{1}$

Pengertian korporasi sebagaimana diuraikan di atas, mengingatkan kita pada "badan-hukum" (rechtspersoon) yang mempunyai makna sebagai suatu perkumpulan atau organisasi yang oleh hukum diperlakukan seperti seorang manusia, yaitu sebagai pengemban hakhak dan kewajiban-kewajiban, dapat memiliki kekayaan, serta dapat menggugat dan digugat dimuka pengadilan. ${ }^{2}$ Contoh badan hukum yang ada di Indonesia antara

\footnotetext{
${ }^{1}$ Soetan K. Malikoe Adil, 1955, Pembaharuan Hukum Perdata Kita. Pembangunan, Jakarta. Hlm. 83.

${ }^{2}$ R. Subekti dan R. Tjitrosoedibio, 1985, Kamus Hukum, Pradnya Paramita, Jakarta. Hlm. 15.
} 
lain Perseroan Terbatas (PT), Yayasan dan Koperasi.

Hal senada juga disampaikan oleh Sudikno Mertokusumo, bahwa apa yang dimaksud dengan badan hukum adalah organisasi atau kelompok manusia yang mempunyai tujuan tertentu yang dapat menyandang hak dan kewajiban. ${ }^{3}$

Pandangan dari sisi hukum perusahaan disampaikan oleh Rudhi Prasetya, yang menyatakan bahwa badan hukum adalah subyek hukum yang mempunyai harta kekayaan sendiri yang cakap melakukan perbuatan perdata dengan akibat dari perbuatannya itu hanya dipertanggungjawabkan sampai pada jumlah harta kekayaan yang ada. ${ }^{4}$

Yan Pramadya Puspa, mengatakan : "Korporasi atau badan hukum adalah suatu perseroan yang merupakan badan hukum; korporasi atau organisasi yang oleh hukum diperlakukan seperti seorang manusia (personal) ialah sebagai pengemban (atau pemilik) hak dan kewajiban, memiliki hak itu adalah PT (Perseroan Terbatas), NV. (Naam Loze Venootsschap) dan Yayasan (Stiching),

\footnotetext{
${ }^{3}$ Sudikno Mertokusumo, 1988, Mengenal Hukum (Suatu Pengantar), Liberty, Yogyakarta. Hlm. 53.

${ }^{4}$ Rudhi Prasetya, 1975. Beberapa Segi Hukum Perusahaan, Majalah Hukum Nomor 2 Tahun Kedua, Yayasan Penelitian dan Pengembangan Hukum (Law Center), Surabaya. Hlm. 47.
}

bahkan Negara manapun juga merupakan badan Hukum. yang dimaksud disini adalah suatu perkumpulan. ${ }^{5}$

Selanjutnya Stewart Kyd dalam $A$ Treatise on the Law of the Corporation, melalui Joel Bakan menggambarkan korporasi sebagai : "Sekumpulan individu yang bersatu dalam satu badan, dibawah satuan khusus, mempunyai rangkaian yang tak terputus dalam bentuk artificial, dan dilindungi, oleh kebijakan hukum, ddengan kapasitas untuk bertindak, dalam beberapa hal, sebagai individu, khususnya dalam mengambil dan memindahkan hak milik, melakukan kontrak obligasi, dan menuntut atau dituntut, menikmati hak istimewa dan kekebabaln secara umum". 6

Dari pendapat para ahli sebagaimana telah diuraikan di atas, dapat ditarik beberapa karakteristik yang penting dari sudut pandang hukum mengenai korporasi sebagai berikut :

1. merupakan suatu perkumpulan atau organisasi;

2. berbentuk badan hukum;

3. pengemban hak-hak dan kewajibankewajiban;

\footnotetext{
5 Yan Pramadya Puspa, 1977, Kamus Hukum, Aneka Ilmu, Semarang. Hlm. 256.

6 Joel Bakan, 2004, The Corporation, FreePress, a Divison of Simon Schuster, Inc., Montreal. Hlm. 16.
} 
4. memiliki harta sendiri yang terpisah dari para individu-individu yang tergabung dalam korporasi itu;

5. dapat menuntut dan dituntut dimuka pengadilan.

Pengertian-pengertian korporasi yang juga badan hukum sebagaimana diuraikan di atas amat berbeda jika dibandingkan dengan pengertian korporasi menurut naskah Rancangan KUHP baru tahun 1991/1992 Pasal 146 yang meliputi juga organisasi atau perkumpulan yang tidak berbadan hukum.

Pertanggungjawaban Pidana Korporasi.

Selanjutnya mengenai apakah Korporasi dapat dipertanggungjawabkan dalam hukum pidana, maka sebelum menjawab pertanyaan itu ada baiknya jika kita mengkaji isi ketentuan dalam Pasal 59 KUHP, isi pasal tersebut jelas menegaskan sebenarnya Kitab Undang-Undang Hukum Pidana kita menganut pandangan bahwa yang menjadi subyek hukum dan dapat dipidana adalah orang dalam arti manusia alami (natuurlijke person) saja, pandangan tersebut bukanlah tanpa dasar melainkan didalam hukum dikenal adanya azas "societas deliquere non postes" yang artinya badan hukum tidak dapat melakukan tindak pidana.

Tidak disangkal bahwa dalam beberapa peraturan perundang-undangan kita (diluar KUHP tentunya), sebagaimana juga telah disebutkan pada bagian terdahulu ada yang mengatur bahwa Korporasi dapat dipertanggungjawabkan secara pidana dan dapat pula dipidana. Namun demikian perlu juga disimak pendapat para pakar mengenai pertanggungjawaban pidana terhadap korporasi ini.

Prof. Oemar Senoadji, mengatakan bahwa kemungkinan adanya pemidanaan terhadap persekutuan-persekutuan, ini didasarkan tidak saja atas pertimbanganpertimbangan utilities, melainkan atas dasar-dasar yang teoritis dapat dibenarkan. $^{7}$

Hal Serupa juga dikatakan oleh Ciynthia E. Carrasco dan Michael K. Dupee : "Corporation can be liable for the actions of their agents regardless of the agents position within the corporation". ${ }^{8}$

Berbeda dengan Boy Mardjono Reksodiputro yang membedakan pertangggungjawaban pada korporasi sebagai berikut : a) Pengurus korporasi sebagai pembuat dan pengurus jugalah

\footnotetext{
${ }^{7}$ Oemar Senoadji, 1984, Hukum (Acara) Pidana Dalam Prospeksi, Penerbit Erlangga, Jakarta. Hlm. 160.

${ }^{8}$ Cynthia E. Carrasco \& Michael K. Dupee, 1999, Corporate Criminal Liability. The American Criminal Law Review, Georgetown University Law Center, Chicago. Hlm. 1.
} 
yang bertanggung jawab; b) Korporasi sebagai pembuat dan pengurus sebagai yang bertanggung jawab; c) Korporasi sebagai pembuat dan juga sebagai yang bertanggung jawab. ${ }^{9}$

Bahwa sekalipun KUHP kita yang sekarang masih berlaku sebagai hukum pidana positif tidak mengakui adanya pertanggungjawaban pidana terhadap korporasi, namun tidak bisa dipungkiri ada puluhan undang-undang telah mengatur mengenai pertanggungjawaban pidana korporasi itu, dan bahkan mengancamnya dengan pidana. Terlepas dari adanya dualism pengaturan mengenai pertanggungjawaban pidana korporasi sebagaimana telah diuraikan di atas, dan pro kontra para pakar mengeni hal tersebut. Kenyataan yang akan dibahas sehubungan dengan pertanggungjawaban pidana terhadap Korporasi adalah pidana apa yang akan dipergunakan sebagai pidana pengganti denda yang paling tepat untuk diterapkan terhadap korporasi yang telah terbukti bersalah melakukan kejahatan.

Sanksi Pidana.

9 B. Mardjono Reksodiputro, 1989, Pertanggungjawaban Pidana Korporasi Dalam Tindak Pidana Korporasi. Fakultas Hukum UNDIP, Semarang. Hlm. 9.
Untuk menjawab permasalahan sebagaimana tersebut di atas kiranya terlebih dahulu perlu dikaji ketentuan tentang pidana dalam hukum positif Indonesia, sebagaimana yang telah diatur dalam Buku Kesatu, Bab II, Pasal 10 Kitab Undang-Undang Hukum Pidana, sebagai berikut :

"Pidana terdiri atas :

a. Pidana pokok.

1. Pidana mati,

2. Pidana penjara,

3. Kurungan,

4. Denda.

b. Pidana tambahan.

1. Pencabutan hak-hak tertentu,

2. Perampasan barang-barang tertentu,

3. Pengumuman putusan hakim."

Disamping ketentuan pidana sebagaimana tersebut dalam Pasal 10 KUHP, sebenarnya di dalam Kitab Undang-Undang Hukum Pidana masih ada jenis pidana yang lain yaitu Pidana Bersyarat sebagaimana dimaksud dalam Pasal 14a ayat (1).

Mengenai sanksi pidana terhadap korporasi yang semenjak dekade terakhir ini mulai banyak disorot karena dipandang dapat melakukan suatu kejahatan yang lazim disebut dengan kejahatan korporasi, dan boleh jadi ancaman pidana yang akan diterapkan dalam undang-undang yang 
mengatur, atau pidana yang akan dijatuhkan berdasarkan putusan hakim terhadap pelaku kejahatan korporasi ini meniru ancaman pidana sebagaimana tersebut dalam Kitab Undang-Undang Hukum Pidana (KUHP), maka disinilah sebenarnya letak perlunya pengkajian mengenai apakah setiap jenis pidana sebagaimana dimaksud dalam Pasal 10 KUHP tersebut telah tepat dan efektif dapat diterapkan terhadap korporasi, sehingga pertanyaan-pertanyaan mengenai apakah korporasi dapat dieksekusi pidana penjara, dan apakah dengan penjatuhan pidana denda telah menimbulkan efek jera bagi Korporasi, atau apakah perlu sanksi pidana yang bersifat mematikan bagi Korporasi sebagaimana pidana mati bagi naturlijke person pelaku kejahatankejahatan tertentu.

Dari urut-urutan pidana pokok sebagaimana Pasal 10 KUHP tersebut di atas, denda merupakan sanksi pidana yang selama ini dianggap paling cocok untuk diterapkan terhadap korporasi. Agar mengenal lebih jauh tentang sanksi pidana, ada baiknya jika diawali dari pengertian "pidana" itu sendiri. Kata pidana berasal dari bahasa sansekerta, yang lazim dipergunakan sebagai padanan dari kata "straf" dalam bahasa Belanda, atau "penalty" dalam bahasa Inggris, atau hukuman dalam bahasa Indonesia, makna kata pidana menurut Prof. Didik Endro Purwoleksono dalam pidato pengukuhannya sebagai Guru Besar pada Fakultas Hukum Universitas Airlangga Surabaya, adalah: "Pidana itu sendiri dari berbagai pandangan para pakar, merupakan suatu nestapa, derita, ketidakenakan, ketidaknyamanan, pengekangan hak-hak seseorang yang dijatuhkan hakim kepada seseorang yang telah terbukti secara sah dan meyakinkan telah melakukan tindak pidana. Hukum pidana sengaja memberikan penderitaan dalam mempertahankan norma-norma yang diakui dalam hukum". ${ }^{10}$

Senada dengan itu Sudarto mengatakan, Pidana adalah nestapa yang diberikan oleh Negara kepada seseorang yang melakukan pelanggaran terhadap ketentuan undang-undang (hukum pidana), sengaja agar dirasakan sebagai nestapa. ${ }^{11}$

Selanjutnya, Roeslan Saleh mengatakan, Pidana adalah reaksi-reaksi atas delik, yang berwujud suatu nestapa yang segaja ditampakan Negara kepada pembuat delik. $^{12}$

10 Didik Endro Purwoleksono, 2008, Pengaturan Sanksi Pidana Dalam Ketentuan Undang-Undang, Airlangga University Press, Surabaya. Hlm. 5.

${ }_{11}$ Sudarto, 1981, Kapita Selekta Hukum Pidana, Alumni, Bandung. Hlm. 109-110.

12 Roeslan Saleh, 1987, Stelsel Pidana Indonesia, Bina Aksara, Jakarta. Hlm. 5. 
Lebih Khusus tentang Pidana Denda.

Sebagaimana telah disinggung di atas dan setelah cukup membahas apa itu pidana, maka kini saatnya membahas mengenai pidana denda. Umumnya Pidana denda dapat diancamkan atau dijatuhkan terhadap delik-delik pelanggaran atau kejahatan ringan, oleh karenanya pidana denda ini mempunyai sifat yang lain jika dibandingkan dengan pidana-pidana pokok lainnya. Sekalipun denda dijatuhkan terhadap terpidana secara pribadi namun oleh orang lain dengan atas nama terpidana dapat melakukan pembayaran denda tersebut kepada Negara, dan tidak ada larangan untuk itu. Ini berbeda dengan pidana mati atau penjara atau pidana kurungan, dalam pidana-pidana ini tidak diperkenankan sama sekali orang lain sekalipun itu atas nama terpidana menggantikan menjalani pidana itu.

Kalau disimak Pasal 30 KUHP, pidana denda sekurang-kurangnya sebesar dua ratus lima puluh rupiah, dan jika denda tidak dibayar maka diganti dengan pidana kurungan (disebut pidana kurungan pengganti denda) sekurang-kurangnya satu (1) hari dan selama-lamanya enam (6) bulan. Dalam hal terjadi pemberatan maka pidana kurungan pengganti denda dapat dijatuhkan untuk selama-lamanya delapan (8) bulan, dan tidak boleh lebih dari itu.

Selanjutnya menurut Pasal 31 KUHP terpidana dapat seketika menjalani pidana kurungan pengganti denda tersebut, dalam hal ia merasa tidak mampu untuk membayar dendanya. Namun apabila hanya sebagian denda saja yang ia bayar, maka pidana kurungan pengganti denda akan dikurangi secara seimbang.

Sebagaimana azas hukum yang tidak tertulis "geen straf zonder schuld" (tiada pidana tanpa kesalahan) yang secara a contrario berarti jika seseorang itu bersalah, maka ia harus dihukum, sehingga law enforcement dapat terjamin pelaksanaannya. Dalam banyak kasus pada kejahatan korporasi pidana yang dijatuhkan adalah pidana denda, dan korporasi dengan berbagai alasan berupaya agar tidak membayar denda, sehingga eksekusi pidana tersebut menjadi macet karena korporasi tidak mungkin menjalani pidana kurungan pengganti denda. Selanjutnya terjadilah law enforcement yang lemah dan tidak berdaya. Ini merupakan jalan buntu yang membutuhkan penyelesaian hukum yang tidak hanya dalam tataran praktis penerapan hukum sehari-hari, melainkan juga secara teoritispun dapat dibenarkan. 
Konsklusi dalam bagian ini adalah pidana denda tidak mungkin berdiri sendiri (mandiri) dalam pertanggungjawaban pidana korporasi, dan oleh karenanya diperlukan adanya pidana pengganti sebagai substitusi jika pidana denda tidak dilaksanakan."Bentuk pidana pengganti denda sebagai pidana substitusi yang sesuai dengan karakteristik Korporasi”.

Sebagaimana telah diuraikan secara panjang lebar di atas bahwa pidana denda tidak mungkin berdiri sendiri dalam pertanggungjawaban pidana korporasi, dan oleh karenanya diperlukan adanya pidana pengganti sebagai substitusi jika pidana denda tidak dilaksanakan. Pertanyaannya adalah bentuk pidana pengganti yang bagaimanakah yang sesuai dengan karakteristik Korporasi.

Karakteristik Korporasi sebagaimana juga telah disinggung pada bagian terdahulu, yang paling menonjol adalah Korporasi itu organisasi yang merupakan subyek hukum dan memiliki harta kekayaan tersendiri terpisah dari harta kekayaan pendiri atau pemegang sahamnya, artinya Korporasi itu adalah organisasi yang merupakan person (orang) yang memiliki harta kekayaan, ia bukan orang (dalam arti organisasi dan subyek hukum) yang tidak memiliki harta kekayaan. Oleh karenanya menurut hemat penulis sesungguhnya bentuk pidana yang paling sesuai dengan karakteristik Korporasi adalah pidana yang berkaitan dengan organisasi, status subyek hukum dan harta kekayaan.

Pidana dari sisi organisasi antara lain pembekuan untuk jangka waktu tertentu hingga pembubaran Korporasi, sedangkan pidana dari sisi status subyek hukum adalah pencabutan status badan hukum, dan pidana dari sisi harta kekayaan adalah denda.

Secara umum para pakar hukum telah sepakat bahwa pidana denda merupakan pidana pokok utama bagi Korporasi, yang dengan demikian penulis merekomendasi urutan pidana bagi Korporasi adalah sebagai berikut :

1. Denda;

2. Pembekuan untuk jangka waktu tertentu;

3. Pencabutan status badan hukum;

4. Pembubaran Korporasi.

Pidana “denda" adalah pidana pembebanan sejumlah uang terhadap dan harus dibayar oleh Korporasi yang terbukti secara sah dan meyakinkan bersalah melakukan tindak pidana berdasarkan putusan Pengadilan yang telah mempunyai kekuatan hukum tetap. Berikutnya yang dimaksud dengan pidana "pembekuan untuk jangka waktu tertentu" adalah 
Korporasi dilarang melakukan semua dan segala kegiatan hingga batas waktu yang ditentukan oleh Hakim berdasarkan putusan Pengadilan yang telah mempunyai kekuatan hukum tetap.

Sedangkan pidana "pencabutan status badan hukum" adalah dengan dicabutnya status badan hukum Korporasi maka segala akibat yang timbul dari perbuatan yang mengatasnamakan Korporasi menjadi tanggung jawab pribadi pengurus berdasarkan putusan Pengadilan yang telah mempunyai kekuatan hukum tetap. Pidana "pembubaran Korporasi" adalah pidana pamungkas yang menyatakan bahwa Korporasi yang bersangkutan telah dibubarkan dan berakibat pada terjadinya likuwidasi.

Selanjutnya rekomendasi pidana "pembekuan untuk jangka waktu tertentu" sebagai pidana pengganti denda manakala denda yang dijatuhkan tidak dibayar oleh Korporasi. Dalam hal terjadi pidana "pembekuan untuk jangka waktu tertentu" dilanggar, maka Jaksa dapat mengajukan pada Hakim agar terhadap Korporasi dijatuhi dengan pidana "pencabutan status badan hukum”.

\section{Penutup}

Kesimpulan
Berdasarkan semua uraian sebagaimana tersebut di atas, penulis berkesimpulan sebagai berikut :

1) Bahwa pidana denda tidak mungkin berdiri sendiri (mandiri) dalam pertanggungjawaban pidana korporasi, dan oleh karenanya diperlukan adanya pidana pengganti sebagai substitusi jika pidana denda tidak dilaksanakan.

2) Bahwa bentuk pidana yang paling sesuai dengan karakteristik Korporasi adalah pidana yang berkaitan dengan organisasi, status subyek hukum dan harta kekayaan. Pidana dari sisi organisasi antara lain pembekuan untuk jangka waktu tertentu hingga pembubaran Korporasi, sedangkan pidana dari sisi status subyek hukum adalah pencabutan status badan hukum, dan pidana dari sisi harta kekayaan adalah denda.

3) Dalam penerapan pidana denda terhadap Korporasi wajib disubstitusikan dengan pidana "pembekuan untuk jangka waktu tertentu"sebagai pidana pengganti.

Saran

Sehubungan dengan apa yang menjadi pokok pemikiran yang pada akhirnya melahirkan suatu kesimpulan, maka selanjutnya penulis mencoba untuk memberikan saran bahwa oleh karena 
karakteristik natuurlijke person berbeda dengan rechtspersoon maka sanksi pidananya pun menjadi berbeda, sehingga perlu adanya pemuatan urutan sanksi pidana bagi Korporasi dalam KUHP yang baru sebagai bagian dari sub system pemidanaan yang khusus diterapkan terhadap Korporasi yakni sebagai berikut :

1) Denda;

2) Pembekuan untuk jangka waktu tertentu;

3) Pencabutan status badan hukum;

4) Pembubaran Korporasi.

Selanjutnya dapat diterapkan pidana "pembekuan untuk jangka waktu tertentu"sebagai pidana pengganti denda manakala denda yang dijatuhkan tidak dibayar oleh Korporasi.

\section{Daftar Pustaka}

Daftar Bacaan :

Andi Hamzah, 1986, Sistem Pidana dan Pemidanaan Indonesia dari Reribusi Ke Reformasi, Pradnya Paramita Jakarta.

1985, Kamus

Hukum, Ghalia Indonesia Jakarta.

Bambang Poernomo, 1981, Pelaksanaan

Pidana Penjara Dengan Sitem

Lembaga Pemasyarakatan, Liberty, Yogyakarta.
B. Mardjono Reksodiputro, 1989, Pertanggungjawaban Pidana Korporasi Dalam Tindak Pidana Korporasi, Fakultas Hukum UNDIP, Semarang.

Cynthia E. Carrasco and Michael K. Dupee, 1999, Corporate Criminal Liability. The American Criminal Law Review, Georgetown University Law Center, Chicago.

Didik Endro Purwoleksono, 2008, Pengaturan Sanksi Pidana Dalam Ketentuan Undang-Undang, Pidato Pengukuhan Guru Besar Fakultas Hukum Universitas Airlangga Surabaya, Airlangga University Press, Surabaya.

Darmabrata, Wahyono \& Ari Wahyudi Hertanto, 2003, Implementasi Good Corporate Governance, Dalam Menyikapi Bentuk-Bentuk Penyimpangan Fudiciary Duty DIreksi Dan Komisaris Perseroan Terbatas. Jurnal Hukum Bisnis, Volume 22 Nomor 6, Surabaya. Joel Bakan, 2004, The Corporation, FreePress, a Divison of Simon Schuster, Inc, Montreal.

Lili Rasjidi dan IB. Wiyasa Putra, 1993, Hukum Sebagai Suatu sistem, PT. Remaja Rosdakarya, Bandung. 
Niniek Suparni, 2007, Eksistensi Pidana Denda Dalam Sistem Pidana Dan Pemidanaan, Sinar Grafika, Jakarta.

Oemar Soenadji, 1984, Hukum Hakim Pidana, Erlangga Jakarta.

1984, Hukum

(Acara) Pidana Dalam Prospeksi,

Penerbit Erlangga, Jakarta.

Peter Mahmud Marzuki, 2005, Penelitian

Hukum, Prenada Media Jakarta.

Philipus M. Hadjon, dan Tatiek Sri

Djamiati, 2005, Argumentasi Hukum,

Gadjah Mada University Press Yogyakarta.

Roeslan saleh, 1983, Stelsel Pidana Indonesia, Aksara Baru, Jakarta.

Romli Atnasasmita, 2002, Pengantar Hukum Kejahatan Perseroan

Terbatas, Sinar Grafika, Jakarta.

Rudy Prasetya, 1983, Kedudukan Mandiri

Dan Pertanggungjawaban dari Perseroan Terbatas, Airlangga University Press, Surabaya. , 1975, Beberapa

Segi Hukum Perusahaan, Majalah Hukum Nomor 2 Tahun Kedua, Yayasan Penelitian dan Pengembangan Hukum (Law Center), Surabaya.

R. Subekti dan R. Tjitrosoedibio, 1985, Kamus Hukum. Pradnya Paramita, Jakarta.

Sudarto, 1983, Masalah Penghukuman dan Gagasan Pemasyarakatan, Alumni, Bandung. 1981, Kapita Selekta Hukum Pidana, Alumni, Bandung.

Soetan K. Malikoe Adil, 1955, Pembaharuan Hukum Perdata Kita. Pembangunan, Jakarta.

Sudikno Mertokusumo, 1988, Mengenal Hukum (Suatu Pengantar), Liberty, Yogyakarta.

Yan Pramadya Puspa, 1977, Kamus Hukum, Aneka Ilmu, Semarang. 